\title{
ВПЛИВ ДЕКОМПРЕСІЇ ЖОВЧОВИВІДНИХ ШЛЯХІВ НА ДИНАМІКУ ПРОЦЕСІВ ЖОВЧОУТВОРЕННЯ І ЖОВЧОВИДІЛЕННЯ ПІСЛЯ ЕКСПЕРИМЕНТАЛЬНОГО ХОЛЕСТАЗУ РІЗНОЇ ТРИВАЛОСТІ
}

\author{
О. І. Дзюбановський, А. А. Гудима
}

Тернопільський державний медичний університет імені І. Я. Горбачевського

\section{IMPACT OF THE BILIARY DUCTS DECOMPRESSION ON DYNAMICS OF BILE PRODUCTION AND BILE EXCRETION AFTER EXPERIMENTAL CHOLESTASIS OF DIFFERENT DURATION}

\author{
O. I. Dzyubanovskyi, A. A. Gudyma \\ Ternopil State Medical University named after I. Ya. Gorbachevskyi
}

\section{Ресрерат}

Мета. Дослідити вплив декомпресії жовчовивідних шляхів на жовчоутворювальну і жовчовидільну функції печінки після експериментального холестазу різної тривалості.

Матеріали і методи. В експерименті на нелінійних білих щурах моделювали обтураційну жовтяницю і вивчали показники жовчоутворення і жовчовиділення.

Результати. Після холестазу протягом 3 діб і реканалізації спільної жовчної протоки (СЖП) відновлення жовчоутворювальної і жовчовидільної фуннцій печінки відзначали через 5 діб; після 7 діб холестазу - через 7 діб; після 14 діб холестазу - пригнічення функціонального стану печінки в усі строки після реканалізації СЖП з тимчасовим покращенням через 9 діб.

Обговорення. Реканалізація СЖП супроводжується зменшенням вмісту в жовчі загальних жовчних кислот і холестеролу, збільшенням літогенних властивостей жовчі та уповільненням ії відтоку. Динаміка та інтенсивність виявлених порушень залежать від тривалості обтурації, максимальні - після 14 діб холестазу.

Висновок. Інтенсивність порушення функціонального стану печінки залежить від тривалості холестазу і прогресує від 3-ї до 14-ї доби холестазу.

Ключові слова: обтураційний холестаз; реканалізація спільної жовчної протоки; жовчоутворення; жовчовиділення; експеримент.

Abstract

Objective.To investigate the impact of decompression of biliary ducts towards the bile production and excretion hepatic function after experimental cholestasis of different duration.

Materials and methods. In experiment on nonline white rats the obturation jaundice was simulated and indices of biliary production and excretion were studied.

Results. After cholestasis during 3 days and recanalization of common biliary duct the restoration of biliary production and biliary excretion function of the liver occurs in 5 days; after 7 days of cholestasis - in 7 days; and after 14 days of cholestasis-inhibition of hepatic functional state in all terms after recanalization of common biliary duct with transient improvement is observed in 9 days.

Discussion. Recanalization of common biliary ductis accompanied by reduction in the common biliary acids and cholesterol contents in bile, by enhancement of the bile lithogenic properties and by slowing-down of its outflow. Dynamics and intensityof the disorders revealed depend upon the obturation duration, they are maximal after 14 days of cholestasis.

Conclusion. Intensity of disorders in the hepatic functional state depends upon cholestasis duration and progresses from the $3 \mathrm{~d}$ to 14 th day of cholestasis.

Keywords: obturation cholestasis; recanalization of common biliary duct; bile production; bile excretion; experiment.

Актуальною проблемою сучасної абдомінальної хірургії $€$ жовчнокам'яна хвороба (ЖКХ). Вона посідає провідне місце в структурі захворювань органів черевної порожнини [1]. ЖКХ часто ускладнюеться порушенням відтоку жовчі. Тривалість холестазу суттєво впливає на ефективність хірургічного лікування, навіть за умови застосування мініінвазивних технологій.

Доведено, що вже $з$ моменту повної обтурації ЖКХ виникають запальні, некробіотичні й дистрофічні процеси в печінці, що супроводжуються прогресуванням ендогенної інтоксикації, процесів ліпідної пероксидації і холестазу [2 - 4].

При декомпресії жовчовивідних шляхів відзначають посилення ураження печінки з формуванням недостатності іiі функції [5].

В цих умовах виникають дистрофічно-некротичні зміни в печінці, що залежить від тривалості обтурації СЖП. Встановлено, що при декомпресії через 3-7 діб холестазу в печінці збільшується кількість ураже- них гепатоцитів, максимальна - через 24 год. При декомпресії через 14 діб деструктивно-некротичні зміни в паренхімі печінки посилювалися [6].

Проте, динаміка відновлення функціонального стану печінки після декомпресії СЖП практично не вивчена. Немає даних про вплив на цей процес тривалості холестазу.

Метою дослідження було вивчення впливу декомпресії жовчовивідних шляхів на жовчоутворювальну і жовчовидільну функції печінки піс- 
ля експериментального холестазу різної тривалості.

\section{МАТЕРІАЛИ I МЕТОДИ ДОСЛІДЖЕННЯ}

Експерименти проведені на 151 нелінійному білому щурі-самці масою тіла 200 - 220 г. Під наркозом тіопентал-натрієм в дозі 50 мг/кг з дотриманням правил асептики і антисептики у дослідних тварин моделювали обтураційну жовтяницю [7]. Здійснювали серединну лапаротомію, перев'язували СЖП монофіламентною ниткою, що не розсмоктується (фірми GORETEX). У першій серії експериментів реканалізацію СЖП проводили в нижній третині через 3 доби, у другій серії - через 7 діб, у третій серії - через 14 діб. Тварин повторно вводили у наркоз, виконували релапаротомію, пересікали нитку, що сприяло відновленню відтоку жовчі.

у кожній серії експериментів в умовах наркозу тіопентал-натрієм вивчали жовчоутворювальну і жовчовидільну функції печінки. Катетеризували СЖП, забирали жовч протягом 2 год перед ії реканалізацією, а також через 1, 3, 7, 9, 14 i 28 діб після неї.

В жовчі, відповідно до рекомендацій [8], визначали питому швидкість жовчовиділення, концентрацію загальних жовчних кислот і холестеролу.

Обчислювали холато-холестероловий індекс: співвідношення вмісту загальних жовчних кислот/холестеролу як показник літогенності жовчі. В подальшому тварин виводили 3 експерименту методом тотального кровопускання з серця.

Під час роботи 3 лабораторними тваринами дотримували міжнародних вимог про гуманне ставлення до тварин відповідно до правил «Европейської конвенції з захисту хребетних тварин, яких використовують 3 експериментальною та іншою науковою метою» (European Convention, 1984).

Отримані цифрові дані обробляли 3 використанням статистичних методів. Вірогідність відмінностей між дослідними і контрольною групами оцінювали 3 використанням програми Statistica («StatSoft, Inc.), США) на основі непараметричного критерію Манна-Уітні.

\section{РЕЗУЛЬТАТИ}

Динаміка швидкості жовчовиділення у тварин за різної тривалості холестазу була різною. Так, на тлі 3-добового холестазу показник через 1 добу після декомпресії СЖП порівняно 3 контролем збільшувався на 29,3\% ( $<$ 0,05); через 3 доби - він зменшувався, проте на 16,6\% перевищував такий у контролі (р < 0,05); починаючи з 5-ї доби - нормалізувався та вірогідно не відрізнявся від показника в контрольній групі (p > 0,05). Після 7-добового холестазу декомпресія СЖП спричиняла істотне зменшення швидкості жовчовиділення впродовж перших 5 діб спостереження - відповідно на 15,3, 13,2, 17,2 і 21,0\%, порівняно $з$ такою в контрольній групі (p < 0,05). Починаючи з 7-ї доби, показник збільшувався і статистично вірогідно не відрізнявся від такого в контрольній групі (p > 0,05). Починаючи з 9-ї доби, він також перевищував рівень, зафіксований на висоті холестазу ( $<<0,05)$.

Після 14-добового холестазу катетеризація СЖП супроводжувалася незначним виділенням жовчі. Швидкість жовчовиділення в усі строки спостереження після декомпресії СЖП виявилася статистично вірогідно меншою, ніж у контролі (р < 0,05). В динаміці відзначали збільшення показника через 5 - 9 діб. В ці строки він навіть вірогідно перевищував такий на висоті холестазу (р < 0,05), проте, починаючи з 14-ї доби, значно зменшувався.

\section{ОБГОВОРЕННЯ}

Впродовж перших 5 діб після декомпресії СЖП швидкість жовчовиділення у тварин за 3-добового холестазу була статистично вірогідно більшою, ніж у тварин за 7-добового холестазу. Починаючи з 9-ї доби, відмінності між цими групами були статистично невірогідні (p > 0,05). Величина досліджуваного показника у тварин за 14-добового холестазу в усі строки спостереження виявилася істотно меншою, ніж в інших групах $(\mathrm{p}<0,05)$.

Аналіз динаміки вмісту в жовчі загальних жовчних кислот свідчив, що на висоті холестазу в усіх групах показник був істотно меншим, ніж у контролі: після 3-добового холестазу - на 43,8\%, 7-добового - на 51,8\%, 14-добового - на 69,9\% ( $<<0,05$ ). Після реканалізації СЖП показник збільшувався, у тварин за 3-добового холестазу досягав рівня контролю через 5 діб ( $\mathrm{p}>0,05)$, за 7 - добового - через 9 діб (р>0,05). У тварин за 14-добового холестазу вміст у жовчі загальних жовчних кислот через 9 діб досягав максимального рівня, проте, він був на 46,1\% меншим, ніж у контрольній групі. В подальшому показник зменшувався, через 14 діб - був на 72,5\% меншим, ніж у контрольній групі $(\mathrm{p}<0,05)$.

На тлі 3-добового холестазу після реканалізації СЖП вміст у жовчі загальних жовчних кислот був в усі строки спостереження більшим, ніж у тварин за 7-добового холестазу, через 1, 5, 9 і 28 діб відмінності були статистично вірогідними ( $<0,05)$. На тлі 14-добового холестазу вміст у жовчі загальних жовчних кислот в усі строки спостереження був меншим і статистично вірогідно відрізнявся від такого в інших групах (р < 0,05).

Вміст холестеролу в жовчі через 1 добу після реканалізації СЖП у тварин за 3 - і 7-добового холестазу порівняно $з$ таким у контрольній групі статистично вірогідно збільшувався (відповідно на 53,6 і 37,1\%, $\mathrm{p}<0,05)$. В подальшому динаміка показника в обох групах була хвилеподібною, проте, від рівня контролю він істотно не відрізнявся ( $>$ > 0,05). У тварин за 14-добового холестазу через 1 добу після реканалізаціі СжП показник, навпаки, був істотно меншим від контрольного (на 39,4\%, $\mathrm{p}<0,05)$. В подальшому він хвилеподібно збільшувався, і через 3 і 14 діб статистично вірогідно не відрізнявся від такого в контрольній групі (р $>0,05)$. Проте, через 28 діб знову суттєво зменшувався - на 48,7 \%, ніж у контролі $(\mathrm{p}<0,05)$.

Після реканалізації СЖП не спостерігали статистично значущих відмінностей у тварин за 3 і 7 - добового холестазу (p > 0,05); за 14-добого холестазу показник у більшості спостережень був статистично вірогідно меншим, ніж у тварин інших груп $(\mathrm{p}<0,05)$.

Динаміка вмісту загальних жовчних кислот і холестеролу в жовчі зумовлювала суттеве зменшення холато-холестеролового індексу, як на висоті холестазу, так і після рекана- 
лізації СЖП. Через 1 добу після їі реканалізації у тварин за 3-добового холестазу цей показник був на 52,3\% меншим, за 7-добового холестазу на 50,9\%, за 14-добового холестазу - на 60,8\%, ніж у контролі (p < 0,05). В подальшому в усіх групах холатохолестероловий індекс збільшувався. У тварин за 3-добового холестазу він досягав рівня у контролі через 5 діб ( $>$ > 0,05), за 7-добового холестазу - через 7 діб (p > 0,05), за 14добового холестазу - через 9 діб (р $>$ 0,05), проте, в подальшому значно зменшувався і через 28 діб був на 46,7\% меншим, ніж у контролі (р < 0,05).

У тварин за 3 - і 7-добового холестазу після реканалізації СЖП холато-холестероловий індекс статистично вірогідно не відрізнявся (р $>0,05)$, так само не було статистично значущих відмінностей показника за 3 - і 14 - добового холестазу через 1 і 3 доби після реканалізації СЖП (p > 0,05) та 7 - і 14-добового холестазу через $1-7$ доби після іiі реканалізації (р > 0,05). В інші строки у тварин за 14-добового холестазу показник був статистично достовірно меншим.

Отримані результати свідчать, що в умовах обтураційного холестазу виникає суттєве порушення функціонального стану печінки, що проявляеться пригніченням жовчоутворювальної та жовчовидільної функцій. Зменшення у жовчі вмісту холатів свідчить про порушення мембранозалежних функцій, пов'язаних з синтезом холатів 3 холестеролу. Ці процеси відбуваються в ендоплазматичному ретикулумі (мікросомальній системі гепатоцитів). Отже, можна припустити, що одним з об'єктів впливу патогенних чинників, зумовлених холестазом і реканалізацією СЖП, є ендоплазматичні мембрани, насамперед, мікросомальної монооксигеназної системи [9]. 3 огляду на низьку субстратну специфічність мікросом гепатоцитів, порушення синтезу холатів вказує на значне пригнічення детоксикаційної функції печінки. В попередніх дослідженнях [10] встановлено, що реканалізація СЖП після 3-добового холестазу вже через 1 добу супроводжується значною інтенсифікацією процесів ліпідної пероксидації, це очевидно, $€$ пусковим механізмом ураження мембран ендоплазматичного ретикулуму і зменшення синтезу холатів. Оскільки пул жовчних кислот, що виділяються 3 жовчю, складається з тих, які повертаються до печінки внаслідок кишково-печінкової рециркуляції, та тих, які синтезуються заново з холестеролу в мікросомальній системі гепатоцитів, можна припустити, що у механізмі зменшення вмісту жовчних кислот важливу роль відіграє зменшення здатності печінки захоплювати жовчні кислоти 3 крові. Все це є підтвердженням формування печінкової недостатності. На тлі 3 - і 7-добового холестазу завдяки процесам саногенезу показник нормалізується відповідно через 5 і 7 діб, після 14-добового холестазу він в усі строки спостереження менший, ніж в інших групах, тимчасово покращується через 9 діб після реканалізації СЖП та знов погіршується через $14-28$ діб.

Щодо вмісту холестеролу в жовчі, його визначає катаболічний пул холестеролу, що захоплюється гепатоцитами і виділяеться у жовч. На тлі 3-добового холестазу вміст у жовчі холестеролу до 3-ї доби після реканалізації СЖП збільшувався, а в подальшому нормалізувався, це свідчило про збільшення здатності гепатоцитів захоплювати холестерол. В той же час, за 7-добового холестазу до 7-ї доби після реканалізації СЖП відзначали пригнічення здатності гепатоцитів захоплювати холестерол $з$ крові, проте, вплив механізмів саногенезу сприяв нормалізації цієї функції, починаючи з 9-ї доби після відновлення пасажу жовчі. На тлі 14добового холестазу і реканалізаціі СЖП вміст холестеролу у жовчі менший, ніж у контролі, що свідчило про значну дисфункцію печінки. До 14ї доби показник збільшувався, навіть досягав такого у контролі, проте, в подальшому, очевидно, внаслідок виснаження адаптаційно-компенсаторних процесів, зменшувався.

Не менш важливе значення має баланс між вмістом холатів і холестеролу. Він забезпечує стабільність жовчної міцели, перешкоджає ii кристалізації [11]. Динаміка холато-холестеролового індексу свідчить, що в умовах обтураційного холестазу і реканалізації СЖП значно збільшуються літогенні властивості жовчі, які за 3-добового холестазу нормалізуються 3 5-ї доби після реканалізації, за 7-добового холестазу - починаючи з 7-ї доби, за 14добового холестазу - через 9 діб 3 подальшим значним збільшенням, що є фактором ризику літогенезу у жовчних протоках.

При аналізі жовчовидільної функції встановлено, що за 3-добового холестазу і реканалізації СЖП відбувається компенсаторне збільшення відтоку жовчі через 1 і 3 доби 3 подальшою нормалізацією швидкості жовчовиділення. За 7-добового холестазу реканалізація СЖП зумовлює істотне зменшення жовчовиділення впродовж 5 діб. Подальша нормалізація свідчить про достатній рівень механізмів саногенезу на тлі 7-добового холестазу, що сприяють нормалізації жовчовиділення через 7 діб після реканалізації СЖП. За 14добового холестазу процес виділення жовчі в усі строки після реканалізації СЖП уповільнений, з періодом тимчасового покращення через 9 діб. Очевидно, це пов'язане з деструкцією мембран біліарного полюсу гепатоцитів і набряку печінки, про що свідчать результати морфологічних досліджень органа [6].

Таким чином, динаміка порушення функціонального стану печінки після реканалізації СЖП залежить від тривалості обтураційного холестазу. За 3-добового холестазу відновлення функціонального стану печінки відбувається протягом 5 діб, за 7-добового холестазу - 7 діб, за 14-добового холестазу функція печінки пригнічена. Через 9 діб після реканалізації СЖП відзначають період тимчасового благополуччя, в подальшому - значне порушення жовчоутворювальної і жовчовидільної функцій печінки.

Отримані результати є теоретичним підгрунтям визначення строків оперативного лікування пацієнтів 3 приводу ЖКХ.

\section{вИсновки}

1. Реканалізація СЖП у щурів після обтураційного холестазу супроводжується порушенням жовчоутворювальної і жовчовидільної функцій печінки, що проявляється зменшенням вмісту в жовчі загальних жовчних кислот і холестеролу, збільшенням літогенних властивостей жовчі та уповільненням ії відтоку. 
2. Вираженість порушень функціонального стану печінки залежить від тривалості обтурації СЖП, прогресує від 3-добового до 14-добового холестазу.
3. За 3-добового холестазу відновлення жовчоутворювальної і жовчовидільної функцій печінки відбувається через 5 діб після реканалізації СЖП, за 7-добового холестазу - через 7 діб, за 14-добового холестазу відзначають пригнічення функцій печінки в усі строки після реканалізації СЖП з періодом тимчасового покращення через 9 діб.

\section{REFERENCES}

1. Badretdinova AR. Analiz vozrastno-polovoy struktury bolnykh zhelchekamennoy boleznyu, idushchikh na planovuyu kholetsistektomiyu. Prakticheskaya meditsina. 2011;(50):60. [In Russian].

2. Borisenko VB, Belov SG, Gorgol NI. Dinamika morfologicheskikh izmeneniy kholedokha, pecheni i drugikh vnutrennikh organov pri modelirovanii mekhanicheskoy zheltukhi v eksperimente. Kharkivska khirurgichna shkola. 2012;(1):46-52. [In Russian].

3. Ratchyk VM, Kosynskyi AV, Prolom NV. Kliniko-laboratorni osoblyvosti eksperymentalnoho kholestazu. Klinichna khirurhiia. 2007;(2):81. [in Ukrainian].

4. Smirnova NG, Chefu SG, Kovalenko AL, Vlasov TD. Vliyanie infuzionnogo gepatoprotektora remansol na funktsiyu pecheni krys na modeli obturatsionnoy zheltukhi. Eksperimentalnaya i klinicheskaya farmakologiya. 2010;73(9):24-7. [In Russian].

5. Hnatiuk MS, Klishch IM, Halei MM. Morfolohichni zminy pechinky ta yikh korektsiia pry zmodelovanii obturatsiinii zhovtianytsi. Shpytalna khirurhiia. 2008;(4):78-82. [in Ukrainian].

6. Orel luM, Dziubanovskyi OI, Shkrobot LV. Strukturni zminy pechinkovoi tkanyny v umovakh zmodelovanoho kholestazu i pislia yoho likvidatsii. Shpytalna khirurhiia. Zhurnal imeni L la Kovalchuka. 2016;(2):45-9. [in Ukrainian].
7. Aller MA, Duran M, Ortega L, Arias JL. Comparative study of macroand microsurgical extrahepatic cholestasis in the rat. Microsurgery. 2004;24(6):442 - 7 .

8. Stefanova OV. Doklinichni doslidzhennia likarskykh zasobiv: metodychni rekomendatsii Kyiv: Avitsenna; 2001. 528 s. [in Ukrainian]

9. Chekman IS, Posokhova KA, Beregovaya YeG. Mikrosomalnaya fermentnaya sistema orhanizma. Kiev; 1996. 80 s. [In Russian].

10. Dziubanovskyi OI. Vplyv dekompresii zhovchovyvidnykh shliakhiv na dynamiku protsesiv lipoperoksydatsii, antyoksydantnoho zakhystu i tsytolizu pislia eksperymentalnoho trydobovoho kholestazu. Visnyk naukovykh doslidzhen. 2016;(4):128-30. [in Ukrainian].

11. Drogovoz SM, Salnikova SI, Skakun NP, Slyshkov VV. Metodicheskie rekomendatsii po eksperimentalnomu izucheniyu zhelchegonnoy, kholespazmoliticheskoy, kholelitiaznoy i gepatoprotektornoy aktivnosti novykh lekarstvennykh veshchestv. Kyiv: FKMZ Ukrainy; 1994. 46 s. [In Russian]. 